DOI: $10.2478 / \mathrm{sjdv}-2019-0018$

\title{
Toxic Epidermal Necrolysis-like Subacute Cutaneous Lupus Erythematosus: a Case Report
}

\author{
Jelena PERIĆ1,3, Branislav LEKIĆ1 , Martina BOSIĆ²,3, Dušan ŠKILJEVIĆ1,3 \\ ${ }^{1}$ Clinic of Dermatovenereology, Clinical Center of Serbia, Belgrade, Serbia \\ ${ }^{2}$ Institute of Pathology, Faculty of Medicine, University of Belgrade \\ ${ }^{3}$ Faculty of Medicine, University of Belgrade, Serbia \\ *Correspondence: Jelana Perić, E-mail: drpericjelena@gmail.com \\ UDC 616.51-002.52-06
}

\begin{abstract}
Cutaneous lupus erythematosus (LE) encompasses a wide spectrum of dermatologic manifestations, including toxic epidermal necrolysis (TEN)-like presentations of acute or subacute cutaneous lupus erythematosus (TEN-like ACLE/SCLE). Although the clinical characteristics and histological features of these rare entities may closely mimic TEN, several subtle differences can help in differentiation between these conditions. We report a case of a patient with SCLE which developed drug unrelated TEN-like blisters after prolonged, intensive sun exposure and focus on a discussion of distinctive features that can be used to differentiate drug-induced TEN and TEN-like presentation of ACLE/SCLE.
\end{abstract}

Key words: Lupus Erythematosus, Cutaneous; Steven-Johnson Syndrome; Signs and Symptoms; Sunlight; Case Reports; Hydroxychloroquine; Treatment Outcome

\section{Introduction}

Cutaneous lupus erythematosus (LE) encompasses a wide spectrum of dermatologic manifestations, including relatively recently described toxic epidermal necrolysis (TEN)like presentations of acute or subacute cutaneous lupus erythematosus (TEN-like ACLE/ SCLE) (1). Although the clinical characteristics and histological features of these rare entities may closely mimic TEN, several subtle differences can help in differentiation between these conditions. In contrast to classic TEN, whose occurrence is usually associated with drug ingestion, TEN-like ACLE/SCLE are often triggered by extensive ultraviolet (UV) exposure and the blistering eruption typically starts on UV-exposed areas (2). A previous history of LE and lupus-specific response in histopathological finding could be additional clues for diagnosis of TEN-like ACLE/SCLE. However, in some cases it can be difficult to distinguish these unusual, vesiculobullous forms of LE from classical TEN both clinically and histopathologically.

We report a case of a patient with SCLE which developed drug unrelated TEN-like blis- ters after prolonged, intensive sun exposure and focus on a discussion of distinctive features that can be used to differentiate druginduced TEN and TEN-like presentation of ACLE/SCLE.

\section{Case Report}

We present a case of SCLE in a 46-year old Caucasian male, which gradually evolved into a TEN-like expression over the course of 4 weeks after prolonged, intensive sun exposure. There was no history of recent infection or drug intake. The slightly painful eruption began on the face and posterior neck but subsequently spread to the upper trunk, shoulders, and arms. The patient had a 1-year history of SCLE characterized by photodistributed annular and polycyclic erythematous plaques. The diagnosis was confirmed by histopathological examination and direct immunofluorescence of skin lesions that were consistent with LE. Lupus band test on sun-protected non-lesional skin was negative. Except an elevated anti-Ro (SSA) antibodies, no other laboratory abnormalities were detected. The disease was well con- 

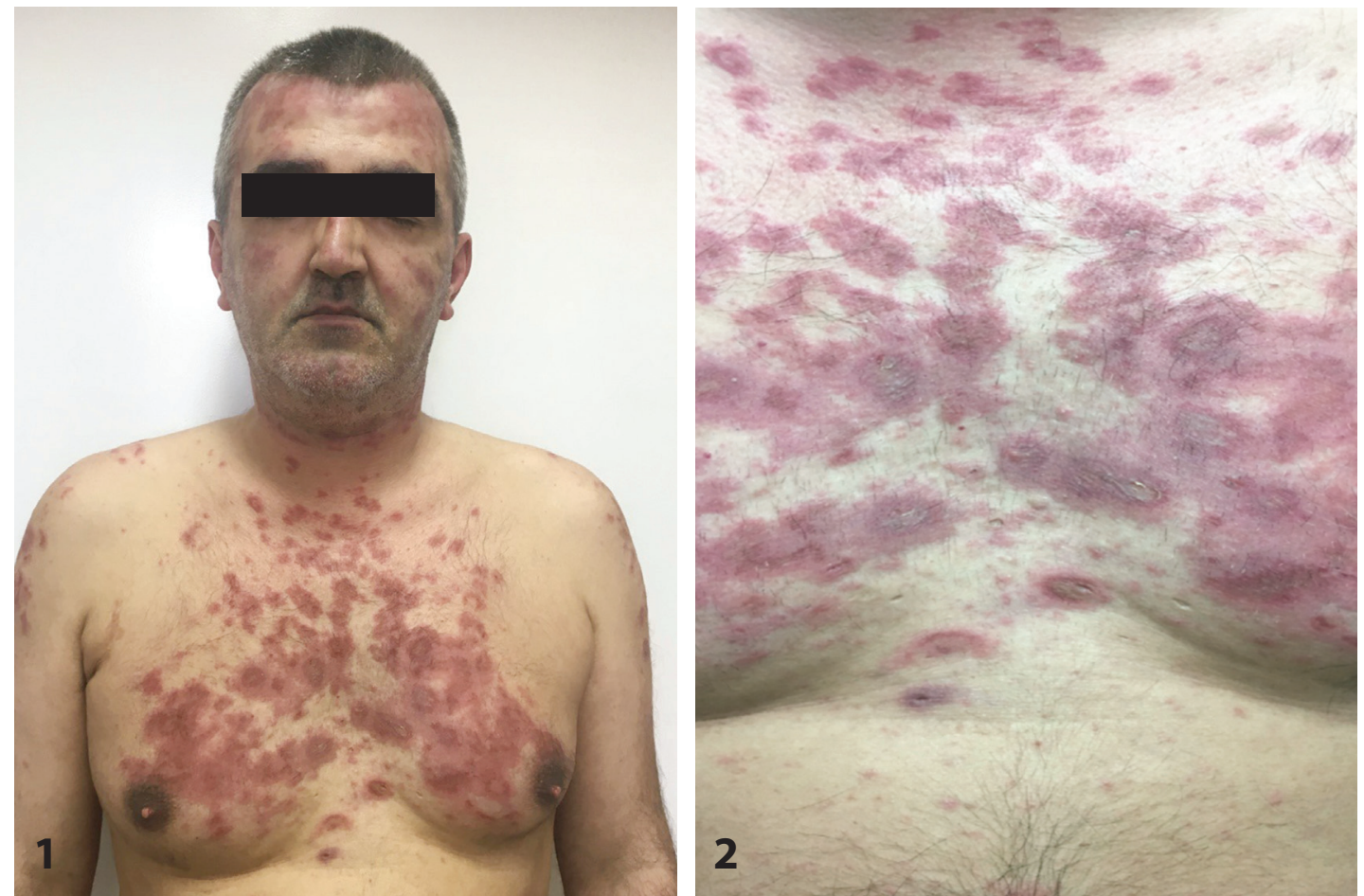

Figures 1 and 2. Dusky erythematous plaques with flaccid blister formation in the presternal region

trolled with hydroxychloroquine and topical corticosteroids over the following year.

On physical examination the patient had symmetrically distributed dusky erythematous plaques, some with central clearing, on the face, posterior neck, chest, upper back, and the extensor surfaces of the upper extremities, with flaccid blister formation in some areas. Typical and atypical targetoid lesions were also observed (Figures 1 and 2). All visible mucous membranes were unaffected. Nikolsky sign was negative. The patient was in good general health.

Histopathology revealed a vacuolar interface dermatitis typical of LE, and it also showed numerous necrotic keratinocytes as well as focally extensive epidermal necrosis. Also, there was a superficial perivascular and periadnexal infiltrate of lymphocytes with interstitial mucin deposition (Figure 3).

Direct immunofluorescent test of the skin lesion was negative. Laboratory investigations demonstrated normal complete blood cell count, serum chemistry, renal function tests and urinalysis. Serologic evaluation revealed only elevated titer of Ro/SS-A antibodies (5 $\mathrm{RU} / \mathrm{ml}$, normal $<15 \mathrm{RU} / \mathrm{ml}$ ). There were no

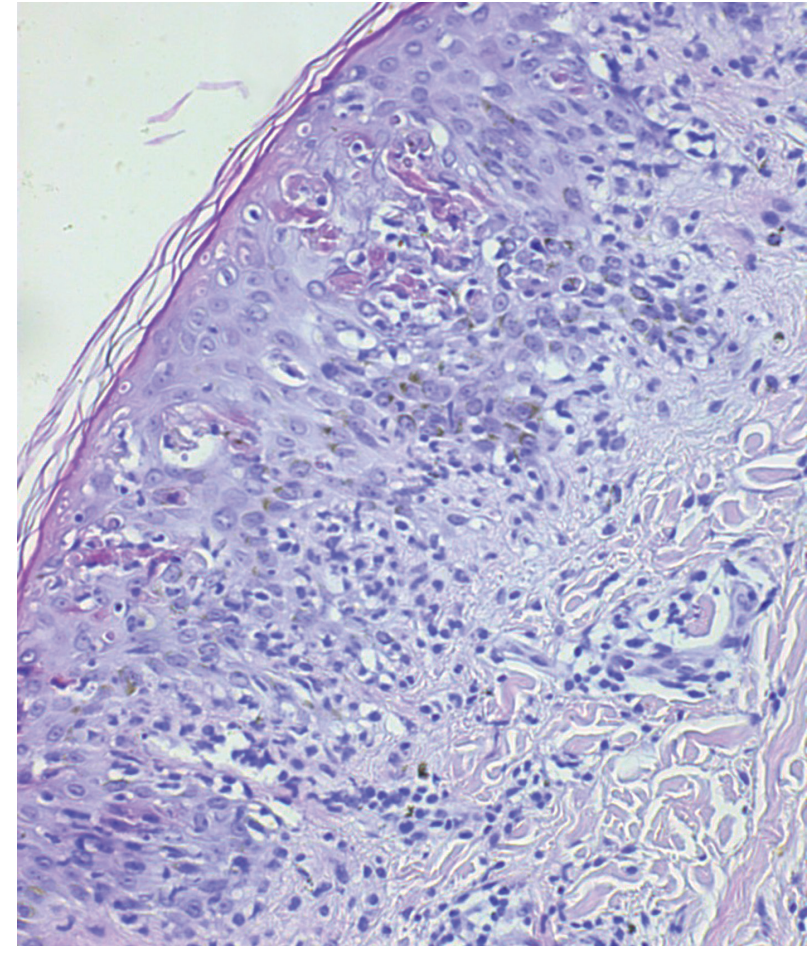

Figure 3. Basal layer vacuolar degeneration with presence of necrotic keratinocytes and mild superficial perivascular lymphocytic infiltrate (HEx200) 
clinical or laboratory signs of other organ involvement.

The diagnosis of TEN-like presentation of SCLE was made based on reported history, clinical presentation and histolopathological findings.

The treatment with oral prednisone 0.6 $\mathrm{mg} / \mathrm{kg}$ tapered slowly over 2 months and hydroxychloroquine $5 \mathrm{mg} / \mathrm{kg}$, combined with potent topical steroid therapy, led to rapid improvement over the following week, with complete resolution of skin lesions within 4 weeks.

\section{Discussion}

In 1977, Gilliam coined the term 'SCLE' for the distinctive, non-scaring, photosensitive form of cutaneous LE that differed from chronic cutaneous LE by several factors $(1,3$, 4). In this subset of cutaneous LE, skin lesions are typically confined to sun-exposed areas, including the upper trunk, shoulders, extensor arms, and sides of the face, while midfacial skin is usually spared (5). They may have either an annular-polycyclic appearance, with raised red borders, peripheral scale and central clearing or papulosquamous presentation clinically similar to psoriasis. An additional important feature of this form of LE is its strong association with the anti-Ro (SS-A) autoantibodies, as more than $80 \%$ of the patients have anti-Ro (SS-A) positivity (6). Unlike the chronic cutaneous form of LE, the skin lesions in this subset of LE typically heal without scarring and atrophy but can result in dyspigmentation (5).

On occasion, vesiculobullous skin lesions may develop in the setting of SCLE as well as ACLE either during the course of the disease or as a part of an initial clinical presentation (5). According to Sontheimer, they are considered as lupus-specific skin eruption as they exhibit typical histopathological features of LE (1). Actually, they represent just a rare morphologic variant of $L E$ that develops due to a massive vacuolar basal cell degeneration occurring as a result of an extensive interface dermatitis (1). Sometimes, these peculiar presentations of ACLE/SCLE could create considerable diagnostic confusion, as their clinical and histopathological characteristics may closely mimic classical drug-induced TEN (7).
In 2004, Ting et al. introduced an umbrella term "acute syndrome of apoptotic panepidermolysis (ASAP)" to include several lifethreatening clinical conditions characterized by flaccid bullae and extensive epidermal detachment, as well as full-thickness epidermal necrosis in histology (2). All of these unusual entities can clinically and histopathologicaly simulate drug-induced TEN as they develop as a result of hyperperacute, massive apoptotic epidermal cell injury, but they differ widely in terms of etiopathogenesis (8). Although quite rarely, except in the classic TEN, TENlike bullous eruption has been described in settings of LE, acute graft-versus-host disease, and pseudoporphyria $(2,9)$.

TEN-like lesions occurring in the context of ACLE/SCLE can create considerable diagnostic difficulties, particularly in the patients without preceding diagnosis of either ACLE or SCLE (7). These rare variants of LE are usually precipitated by extensive UV exposure and display evident photodistribution $(2,9)$, as it was the case in our patient. Moreover, certain features like slow onset and a gradual progression of blistering eruption, annular lesions, negative Nikolsky sign, absent or only mild mucosal involvement, absence of systemic symptoms, positive autoimmune serology, a less severe clinical course, good responses to corticosteroid therapy and lack of evidence of high risk drug intake favor a diagnosis of TEN-like ACLE/SCLE clinically. Furthermore, junctional vacuolar degeneration, a thickened basement membrane zone $(B M Z)$, the presence of solitary necrotic keratinocytes in the lower epidermis, periadnexal and perivascular lymphocytic infiltrates with melanophages, and interstitial mucin deposition point to LE histopathologically (1014). Some of these subtle clues, including subacute progression, distinct photodistribution with annular lesions, negative Nikolsky sign, absence of mucosal involvement and systemic symptoms, and markedly increased titer of anti-Ro (SS-A) antibodies combined with typical LE histopathological features helped us to make the diagnosis of TEN-like expression of SCLE in our patient and to differentiate it from classic TEN. 


\section{Conclusion}

Photodistributed TEN-like bullous eruptions in patients with SCLE can mimic TEN, a rapidly progressive mucocutaneous reaction usually associated with medication use. Our case represents this rare and unusual expression of SCLE and also highlights the difficulties in differentiating between classic druginduced TEN and TEN-like SCLE, especially when LE has not been previously diagnosed.

\section{References}

1. Sontheimer RD. The lexicon of cutaneous lupus erythematosus - a review and personal perspective on the nomenclature and classification of the cutaneous manifestations of lupus erythematosus. Lupus. 1997;6(2):84-95.

2. Ting W, Stone MS, Racila D, Scofield RH, Sontheimer RD. Toxic epidermal necrolysis-like acute cutaneous lupus erythematosus and the spectrum of the acute syndrome of apoptotic pan-epidermolysis (ASAP): a case report, concept review and proposal for new classification of lupus erythematosus vesiculobullous skin lesions. Lupus. 2004;13(12):941-50.

3. Gilliam JN. The cutaneous signs of lupus erythematosus. Continuing Education for the Family Physician. 1977;6:34-70.

4. Mutasim DF. Severe subacute cutaneous lupus erythematosus presenting with generalized erythroderma and bullae. J Am Acad Dermatol. 2003;48(6):947-9.
5. Lee AL, Werth PV. Lupus erythematosus. In: Bolognia JL, Schaffer JV, Cerroni L, editors. Dermatology. 4th ed. Philadelphia, PA: Mosby Elsevier; 2017. p. 662-80.

6. Lin JH, Dutz JP, Sontheimer RD, Werth VP. Pathophysiology of cutaneous lupus erythematosus. Clin Rev Allergy Immunol. 2007;33(1-2):85-106.

7. Paradela S, Martínez-Gómez W, Fernández-Jorge B, Castiñeiras I, Yebra-Pimentel T, Llinares P, et al. Toxic epidermal necrolysis-like acute cutaneous lupus erythematosus. Lupus. 2007;16(9):741-5.

8. Monga B, Ghosh S, Jain V. Toxic epidermal necrolysislike rash of lupus: a dermatologist's dilemma. Indian J Dermatol. 2014;59(4):401-2.

9. Patrício P, Ferreira C, Gomes MM, Filipe P. Autoimmune bullous dermatoses: a review. Ann N Y Acad Sci. 2009;1173:203-10.

10. Ziemer M, Kardaun SH, Liss Y, Mockenhaupt M. Stevens-Johnson syndrome and toxic epidermal necrolysis in patients with lupus erythematosus: a descriptive study of 17 cases from a national registry and review of the literature. Br J Dermatol. 2012;166(3):575-600.

11. Boontaveeyuwat E, Silpa-archa N, Kulthanan K. Toxic epidermal necrolysis-like acute cutaneous lupus erythematosus (TEN-like ACLE) in SLE patients: a report of two cases. Asian Pac J Allergy Immunol. 2012;30(1):83-7.

12. Ranario JS, Smith JL. Bullous lesions in a patient with systemic lupus erythematosus. J Clin Aesthet Dermatol. 2014;7(9):44-9.

13. Mandelcorn R, Shear NH. Lupus-associated toxic epidermal necrolysis: a novel manifestation of lupus. J Am Acad Dermatol. 2003;48(4):525-9.

14. Ryan E, Marshman G, Astill D. Toxic epidermal necrolysis-like subacute cutaneous lupus erythematosus. Australas J Dermatol. 2012;53(4):303-6.

\title{
Subakutni kožni eritemski lupus nalik toksičnoj epidermalnoj nekrolizi: prikaz slučaja
}

\begin{abstract}
Sažetak
Kutani lupus eritematosus (LE) može imati širok spektar dermatoloških manifestacija, uključujući prezentaciju akutnog ili subakutnog kutanog lupusa eritematosus (TEN-like AKLE/SKLE) nalik toksičnoj epidermalnoj nekrolizi (TEN-like). lako kliničke i histopatološke karakteristike ovih retkih entiteta mogu u značajnoj meri podsećati na TEN, nekoliko suptilnih razlika može
\end{abstract}

pomoći u diferenciranju ovih oboljenja. Prikazujemo pacijenta sa SKLE kod koga je došlo do pojave bula nakon prolongiranog, intenzivnog izlaganja suncu, koje su klinički podsećale na TEN. Fokus ovog rada je na specifičnim obeležjima TEN-like prezentacije AKLE/ SKLE, kao i na razlikama u odnosu na lekovima indukovanu TEN.

Ključne reči: Kutani eritemski lupus; Steven-Johnsonov sindrom; Znaci i simptomi; Sunčeva svetlost; Prikazi slučajeva; Hidroksihlorohin; Ishod terapije

Received 31.10.2019.

Accepted 4.11.2019. 